\title{
Lumbar Discectomy. Why Romanian Spine Surgeons and Neurosurgeons Need a Paradigm Shift?
}

Horatiu Alexandru MOISA ${ }^{1,2}$, Dan Aurel NICA ${ }^{3,6}$, Eugen Cezar POPESCU ${ }^{4}$, Aurel George MOHAN ${ }^{5}$, Gabriel IACOB ${ }^{1,2}$, Alexandru Vlad CIUREA ${ }^{2,6}$

\begin{abstract}
Low back pain and its management can be briefly summarized as an entire industry per se. As the general age of the population increases more and more patients find themselves hospitalized with degenerative disorders of the spine which might not always mandate surgery. This article wishes to illustrate the negative tendencies regarding the increasing number of patients frequently receiving ill-advised surgery for low back pain and the consequences that further implicate the healthcare system and the economy. At the same time the authors wish to highlight the need for a national database of patients operated for spine disease and discuss a few key-items spine surgeons and neurosurgeons need to consider prior to operating patients with degenerative diseases of the spine.
\end{abstract}

Keywords: spine surgery, preoperative assessment, surgical indication, complications, national registry.

\section{Rezumat}

Durerea lombară joasă și managementul său pot fi descrise pe scurt ca reprezentând o întreagă industrie. Dată fiind creșterea vârstei generale a populației, un număr din ce în ce mai mare de pacienți sunt spitalizați cu afecțiuni degenerative ale coloanei vertebrale. Aceste afecțiuni însă, pot să nu aibă întotdeauna indicație chirurgicală, iar de multe ori unii pacienți ajung să fie supuși unor intervenții chirurgicale cu scop curativ, dar care în realitate ajung să dăuneze pe termen lung. Scopul acestui articol este de a evidenția o problemă majoră emergentă a sistemului de sănătate prin numărul constant crescător de pacienți care sunt supuși (de multe ori în mod nejustificat) intervențiilor chirurgicale spinale lombare - în contextul unor suferințe degenerative - precum și consecintele semnificative ale acestui aspect. În același timp, autorii doresc să sublinieze importanța construcției unui registru național pentru pacienții operați la nivelul coloanei vertebrale discutând în același timp câteva aspecte preoperatorii importante pentru neurochirurgi și chirurgi spinali care trebuie avute în vedere înaintea stabilirii indicației chirurgicale a unei suferinte lombare.

Cuvinte cheie: chirurgie spinală, evaluare preoperatorie, indicație chirurgicală, complicații, registru național.

\footnotetext{
${ }^{1}$ Department of Neurosurgery, Emergency University Hospital, Bucharest, Romania

${ }^{2}$ Department of Neurosurgery, „Carol Davila” University of

Medicine and Pharmacy, Bucharest, Romania

${ }^{3}$ Department of Neurosurgery, "Grigore Alexandrescu" Emergency

Children's Hospital, Bucharest, Romania

${ }^{4}$ Department of Neurosurgery, "Nicolae Oblu" Emergency

University Hospital, Iasi, Romania

${ }^{5}$ Department of Neurosurgery, Bihor County Emergency Hospital,

Oradea, Romania

${ }^{6}$ Department of Neurosurgery, Sanador Hospital, Bucharest,

Romania
}

\section{Corresponding author.}

Horatiu Alexandru MOISA, Department of Neurosurgery, Emergency University Hospital, Bucharest, Romania. E-mail: horatiumoisa@yahoo.com 


\section{INTRODUCTION}

Low back pain and the management of low back pain could be summarized briefly as an entire industry. As life expectancy increases and the general age of the population rises, more and more patients are diagnosed with degenerative disease of the spine. Multiple fields of medicine (neurosurgeons, neurologists, orthopedists, psychiatrists, psychologists, pharmacologists, podiatrists, osteopaths and so on) race in finding new cures and elaborating new strategies concerning the management of low back pain, degenerative disc disease and associated symptoms.

Given the multitude of unfiltered or unreliable information available, the general lack of critical thinking in the population, medical marketing, novel unproven surgical techniques and so-called "revolutionary" products, the beneficiary of these efforts, the patient, is unfortunately left without a real capacity to decide what's best for him.

Often, as true victims of heedless publicity and ongoing controversies, patients desire only freedom from pain, a good quality of life and cheap solutions to their suffering, however, recklessness, poor judgement, inadequacy of surgical technique employed, bravado behavior, late treatment, misdiagnosis, lack of medical education and last but not least poor external influence will occasionally lead our patients to undergo a surgical intervention, with questionable results, which instead of alleviating symptoms will lead to the worsening of the condition.

Low back pain has a prevalence of approximately $60-80 \%$ of the general population and represents the second most frequent reason for which patients require medical attention. In about $5-10 \%$ of all patients, symptoms will have occurred for more than 3 months (which is a risk-associated factor in itself) (1-4. $^{1-4}$

As medical addressability has improved over the last decades, neurosurgeons began noticing (as early as 1985 in the case of Romania) $)^{5}$ a constant increase in the number of patients reaching hospitals with lumbar pain, highlighting an upcoming emergent social problem. Following close-by, the number of patients which were operated on, for lumbar disc disease, has also increased. What remains unfortunately unchanged is the constant rate of complications and surgical failure reported in the literature (which goes as high as $46 \%$ in some situations). Under these circumstances, it is easy to understand and to predict the fact that more and more patients will be encumbered by the negative results of a poorly performed or ill-advised surgery.
As mentioned above, this issue is rapidly becoming a major problem of public healthcare in Romania and around the world ${ }^{6-8}$.

To prevent an increase in the number of patients affected by unsuccessful lumbar spine surgery the authors suggest a series of measures which should help raise surgeons' awareness regarding the possible pitfalls of treating low back pain and performing lumbar discectomies. The authors strongly underline the urgent need to develop a registry for patients with spine surgery in Romania, as this tool will be invaluable in further studies of the phenomenon in years to come. Last but not least it is the authors' opinion that an additional tool to help stratify associated surgical risk is needed to help filter out potentially unsuitable patients for lumbar discectomy.

\section{MATERIAL AND METHODS}

The early works of Elsberg ${ }^{9}$ or Putti ${ }^{10}$ at the beginning of the $20^{\text {th }}$ century, followed by Mixter and Barr's seminal paper from $1934^{11}$ have opened the way to understanding and treating sciatica following lumbar disc herniation. If initial management strategies in such cases were usually centered around decompressive laminectomies, modern techniques have come a long way and employ the use of endoscopes, surgical microscopes, loupes, high-speed drills, microscopic instruments, electrophysiologic studies, minimal incisions, high resolution MRI scans and many more. Despite technical advances nevertheless, the two main factors involved in the treatment of low back pain and disc hernias are still the patient and the surgeon. Regardless of the technique you use, never forget that "a fool with a tool is still a fool". Don't be afraid of operating, but perform surgery only when your actions bennefit the patient!

\section{Psychologic factors}

As clinical situations are never the same, symptoms for the same disease may vary from one patient to another. Pain can be perceived differently, patients have different psychologies and coping mechanisms, different expectations regarding surgery, different education and different degrees of compliance to treatment. At the same time some surgeons prefer to operate early while other surgeons prefer to operate only when needed; some surgeons perform discectomies, other surgeons perform sequestrectomies, some surgeons prefer endoscopic approaches, other like to perform classic interventions and so on. Bear in mind that surgeon psychology always influences the choice of treatment. 
Under these circumstances the indications for surgical treatment may be blurry, or even manipulated. As the private medical sector is continuously growing, surgical techniques may be misused or their limitations may be maliciously overlooked in the desire to be competitive to one's peers or have better publicity. Some surgeons may use too small an approach, while others may over instrument the spine, some surgeons may only perform minimal gestures while others perform extensive surgeries. All these negative factors and many more others make our patients more susceptible to Failed Back Surgery Syndrome and may potentially generate lawsuits, increased morbidity, extended sick leaves, decreased quality of life, higher financial reimbursements which in turn will come back and exert pressure on the medical system under the shape of enormous amounts of money spent.

\section{Statistics, registries and data collection}

Literature data available for the United States of America for the decade 1998-2008 showcases an increase in the number of lumbar fusions from 77.682 (in 1998) to 210.407 (for 2008). At the same time, in 2002, American surgeons had performed over 1.000.000 interventions on the spine. From a cost perspective, the same data states that the cost of treatment for low back pain in 2004 alone went (for the U.S.) as high as 16.000.000.000 USD ${ }^{12}$.

As misfortune has it, no comparison can be made with the Romanian situation, as no data regarding the general situation of spine surgery exists for Romania. It is therefore nearly impossible to conduct a nationwide study about lumbar disc herniations (or any other disease mandating surgery of the spine). Nation-wide surgical impact on patient quality of life cannot be assessed, the most frequently used techniques cannot be assessed, their complications and management of said complications cannot be assessed and so on. It is therefore IMPERATIVE to have such a registry put in place urgently. There is a similar situation for neurosurgical patients as well.

There are many well established registries that could be used as a model for a potential national database for patients with spine surgery. Such a tool would be of great use for neurosurgeons or spine surgeons conducting studies regarding interventions on the spine. For example, Norway's NORSPINE ${ }^{13}$ registry is a solid research tool for evidence-based medicine. The registry helps neurosurgeons everywhere understand the epidemiology of spine disease in Norway and lets researchers

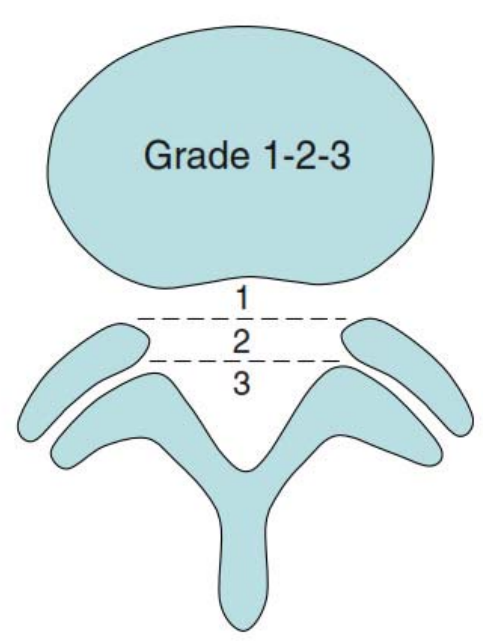

Figure 1. Size of herniation based on axes drawn between medial margins of facet joint articulations. From: L.W. Mysliwiec et al., MSU Classification for herniated lumbar discs on MRI: toward developing objective criteria for surgical selection. Eur Spine J (2010) 19:10871093.

compare data and results based on surgical technique used for different pathologies. Other notable registries include the AOSPINE registry, the Eurospine registry ${ }^{14}$, the North American Spine Society Registry ${ }^{15}$ and many others.

\section{Indication of surgery}

Another crucial aspect that needs to be approached, regarding increasing surgical safety for patients with

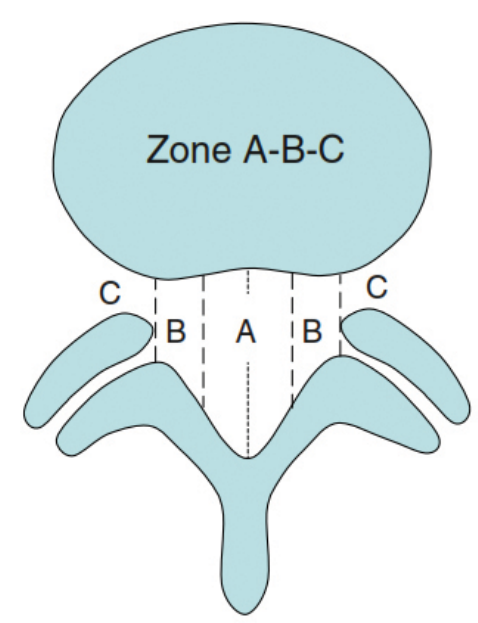

Figure 2. Zoning of herniation based on paralel axes perpendicularly drawn through each of the 4 segments composing the intrafacet line From: L.W. Mysliwiec et al., MSU Classification for herniated lumbar discs on MRI: toward developing objective criteria for surgical selection. Eur Spine J (2010) 19:1087-1093. 
lumbar disc herniations, is understood that non-radiating low back pain will almost never be healed by surgery. Prior to extensive examination, a spine surgeon or a neurosurgeon will order an MRI or a CT scan or even both. Imaging alone is never an argument for surgery as the patient's clinical status may not require intervention despite herniation being visible. Surgery should always be considered only after failed conservative treatment or in cases of emergency.

Always try to use the quantitative herniation criteria. In the opinion of many authors, surgery should be performed for lumbar disc herniations only when their size surpasses a certain threshold in what regards size. In this respect, Mysliwiec et al., described a truly remarkable quantification system 16 for lumbar disc hernias which takes into account bone anatomy of the patient, herniation volumetry and when used is able to generate favorable results in more than $90 \%$ of cases. Mysliwiec et al measure the size and level of herniations where maximal extrusion is noticed. This is done in relation with a line drawn transversely across the spinal canal to and from the medial edges of the facet joint articulations.

a
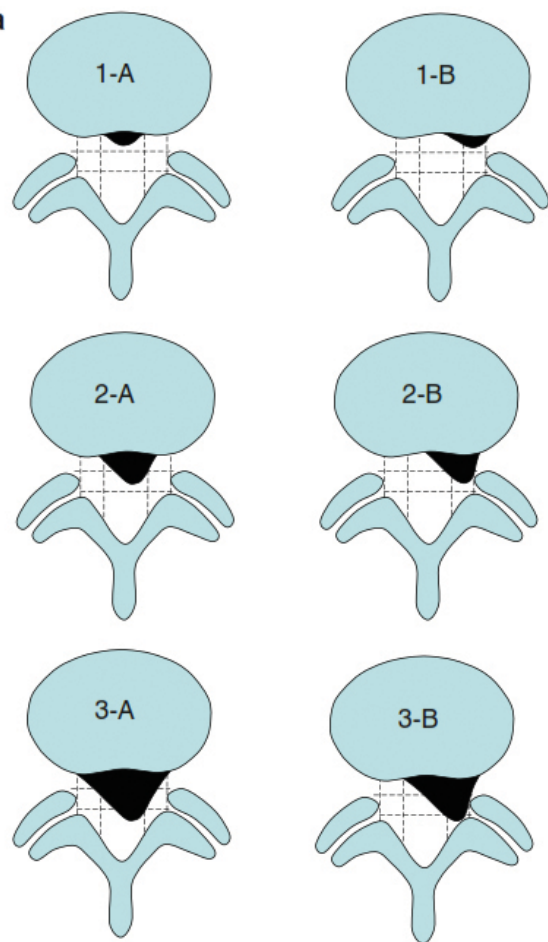

Herniation size is graded 1, 2 and 3 based on how much extrusion there is. If extrusion reaches less than $50 \%$ of the distance between the non-herniated aspect of the disc and the intrafacet line it is described as size 1. If the herniation reaches more than $50 \%$ of the distance, it is characterized as a size 2 . If the herniation reaches beyond the intrafacet line it is characterized as a size 3 (Figure1).

The second part of objectively characterizing a disc herniation is, in Mysliwiec's opinion zoning. The intrafacet line is divided into 4 equal segments. The two middle segments represent zone A. The outer 2 segments represent zone $\mathrm{B}$. The foraminal aspect of the nerve roots is considered to be zone $\mathrm{C}$.

When combining the two criteria - size and zoning (Figure 3), a surgeon may better understand whether or not surgery is indicated, as size 2 and 3 lesions yield the best surgical results; constrained herniations $2 \mathrm{~B}$ and $2 \mathrm{AB}$ lesions frequently require surgery and $2 \mathrm{~A}$ lesions can sometimes respond to conservative treatment. Last but not least, the MSU Classification can also be used as standard language regarding lumbar disc herniati-

b
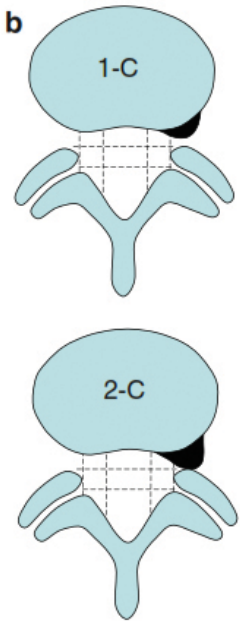
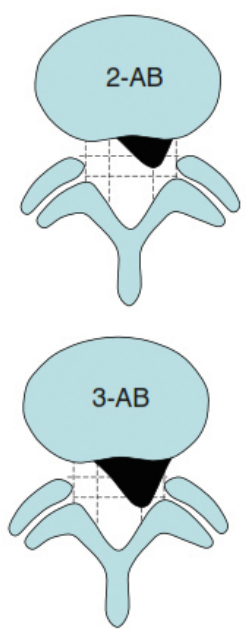

Figure 3. Possible combinations of zoning and sizing From: L.W. Mysliwiec et al., MSU Classification for herniated lumbar discs on MRI: toward developing objective criteria for surgical selection. Eur Spine J (2010) 19:1087-1093. 
ons. This aspect would prove extremely useful when constructing a national registry with multiple contributing physicians.

Surgical indication for a patient with low back pain (who underwent imaging) should always be considered when the surgeon or attending physician notices one of the following:",

- Failure of conservative treatment

- Worsening of symptoms

- Fulfillment of the quantitative herniation criteria

- Cauda equina syndrome

- Motor and/or sensitive deficit (sudden or progressive)

- Bladder / Bowel dysfunction (resulting from compression)

- Radiating pain (sciatica) on one or both legs

- Segmental instability at flexion-extension tests

- Intolerable levels of pain

* Note that patient symptoms should perfectly overlap the expected clinical picture based on Imaging findings, otherwise surgery might not be the best treatment method available and supplementary testing may be needed.

** Bear in mind this article refers to Lumbar disc herniations without other degenerative phenomena

\section{Comorbidities, examination and discussions}

Careful examination and talking with the patients should always be performed. Old semiologic thinking stated that a doctor should be able to figure out what is wrong with his patient in 5-10 minutes. In the authors' opinion this no longer applies when dealing with surgical patients, especially in neurosurgery, and most importantly when dealing with pain.

Our surgical interventions may save lives and improve quality of life, but at the same time, they may very well have devastating consequences. It is therefore crucial to understand what the patient expects from surgery and it is vital that the patient understands how and whether surgery will benefit him. Always mention complications and how they are treated. Such discussions, although time consuming, may prevent a lawsuit, especially when the patient signs in his chart that such a discussion took place.

Frequently overlooked comorbidities include cardiovascular conditions, psychiatric conditions, adult spinal deformity, smoking, sedentariness and chronic alcoholism. Quality of life in such patients should always be tested both as a baseline, prior to surgery, and periodically. Relevant data should always be noted in a dedicated registry as described above. Routine longitudinal radiographs of the spine should be performed and spino-pelvic parameters should always be recorded prior to surgery as interventions on the spine might trigger an otherwise un-noticeable spinal imbalance.

Psychiatric conditions need to be carefully assessed as such patients may be non-compliant in the postoperative period, may provide erroneous feed-back, or may be having pain unrelated to imaging findings. Nevertheless, psychiatric disorders should never be a criteria for depriving a patient of a surgical intervention which could in theory improve his symptoms or even save limb function.

Smoking, sedentariness and alcoholism should be mandatory recorded as they create together a synergism of physical and chemical stress in the affected region. The patient should always be encouraged and helped to quit smoking and drinking. A healthy lifestyle should always be promoted by surgeons, with physical activity at its core. Segmental instability should always be carefully assessed and treated with spinal fusion where applicable. Alternatively, bracing may be a useful method in patients with decreased bone quality or suffering from various rheumatologic conditions.

\section{Surgical technique}

Even though surgical science currently offers many ways to approach a diseased organ, in the field of spine surgery there are 4 main theories regarding how spine surgery should be carried out: classical open surgery, surgery with loupe magnification, endoscopy or surgical microscopy. In the author's opinion, the surgical microscope should always be used when possible for several reasons:

The surgical microscope offers the best (coaxial) illumination, depth of field and working distance. When properly wielded the surgical microscope is a formidable tool which enables surgeons to operate using minimal incisions (borderline minimally invasive) between 3 and $6 \mathrm{~cm}$ long. Microscopes offer the possibility of high definition recording (which is another useful aspect if a lawsuit is to occur). The surgeon can easily demonstrate that he performed the surgery flawlessly.

Surgical loupes lack several key features the microscope offers: the working distance is fixed unlike the surgical microscope's variable working distance, illumination is para-axial, head motion might disturb the surgeon's focus (especially under magnification larger than $2.5 \mathrm{x}$ ), devices are usually bulky and cumbersome to wear, especially when using a fiber-optics light source. Recording is impossible. Unlike the surgical microscope, head loupes grant the advantage of magnification only to the main operator while the aid can't use 
a second set due to ergonomics. Using the microscope both surgeons have a clearer picture of what is going on in the surgical field.

Endoscopy per se has revolutioned surgery by enabling surgeons (and neurosurgeons implicitly) to treat areas of the body otherwise unreachable. A third ventricle tumor for example would take precious hours to reach before surgical resection. When an endoscope is involved, reaching a third ventricle tumor takes about 10-15 minutes for an experienced surgeon. In lumbar surgery, endoscopes are frequently used to minimize incisions and tissue damage when trying to resect extraforaminal herniations. Unlike neuroendoscopy, spine surgeons use a tube retractor to create a surgical corridor to the lesion and thus reduce the need for extensive muscle dissection.

Spinal endoscopy can be employed in situations a disc space needs to be inspected or when the surgeon needs to see from a different angle what's going on in the surgical field. Straight or angled lenses may be used for a wide variety of lesions. On the other hand, the downside of spinal endoscopy is that although visualization is very good in the field of view the instrument offers, the field of view is most of the times severely limited, which in turn doesn't allow to search for a free disc fragment or check behind a nerve root. Fragments migrated under the posterior longitudinal ligament may be overlooked or not identified at all. Magnification may fool the surgeon into believing he resected a large enough portion of the disc however this might not always be truthful to reality. Haptic feedback (the surgeon's sensation to touch) is yet to be implemented. These aspects have led to a long standing series of controversies in the field of spinal surgery as some advocate classic surgery is better than endoscopy.

Keep in mind that surgical techniques such as open surgery without magnification, might be more prone to infection, tissue damage (vascular, dural or nervous) and in our opinion should be avoided. Always keep in mind that it's better to perform surgery in a facility outfitted with as many amenities and devices as possible. A surgical situation may be outlined and perhaps planned, remember however to expect the unexpected.

Other procedures such as laser coblation, chemonucleolysis, nucleoplasty etc. should always be reserved for particular cases when patients may not undergo surgery (clotting disorders, respiratory conditions, cardiac conditions), or where vital prognosis is severely affected (for example multiple metastases). Remember that a poorly performed non-surgical intervention may alter prognosis for future surgery. Temporize and medicate patients rather than having them undergo pointless procedures.

\section{Risk assessment}

Prior to surgery, clear check-lists should always be verified. Check the patient's data, review the symptoms, review the surgical level and side, mark them clearly, where possible use intraoperative radiology (even for basic interventions) If helpful medical devices are available, why not use them?!

Always consider the patient's data: age, comorbidities, treatments, daily routines. How long has the patient being in pain? Does he expect a disability reimbursement? What activities is he able to perform while in pain? Always be very careful about the patient's attitude towards returning to work as some patients may actively seek an early retirement or disability pension.

Note that the number of patients returning to normal life partially reflects the surgeon's labor. Recommend ceasing of work only when required, as patients which interrupt active work become a burden for the economic and healthcare system. Not all patients undergoing lumbar spine surgery need ceasing of work. Keep in mind that labor reorientation does exist.

Always be attentive of patients operated in other clinics or with prior interventions, as the number of sustained surgeries is a risk factor for failed back spine surgery. Never perform rushed surgery in non-critical patients as decision-making may be biased.

When coming up with the surgical plan try and establish your strategy in 10-12 clear steps. For each step identify potential hazards. Note them down on a piece of paper. When finished, retrace your steps. Try and preempt where and why complications might occur. If complications are to occur, a good surgeon already knows what went wrong and where. Review the anatomy and the technique as nobody is beyond error. During surgery remember that the best outcome for the patient is your goal, however remember that if complications arise, solving said complication should become your number one priority. Ego should always come last.

\section{Rehabilitation}

Rehabilitation in Romania is one of the most under budgeted medical specialties. Decision factors and policy-makers should understand that professionals in this field may mitigate serious unwanted complications of surgery. It is therefore highly recommended to have 
a close collaboration with doctors dealing with medical rehabilitation.

\section{To conclude:}

- The lack of relevant medical data regarding lumbar spine surgery is a major setback for research if we are to learn from our mistakes and improve ourselves. A national medical registry for patients with lumbar disc herniation is a crucial tool urgently needing development. All neurosurgeons and spine surgeons should be encouraged to periodically report the status of their patients.

- Constant reviewing of what we know, what others know, how we do it and how others do it represents a must-do for surgeons trying to better their practice.

- New guidelines regarding the assessment and stratification of surgical risk for patients with radiating low back pain and associated conditions are vital for our patients' outcome.

- As no case is similar to another, the surgical strategy should be always custom-made for each of our patients.

\section{References}

1. Hoy, D., March, L., Brooks, P., Blyth, F., Woolf, A., Bain, C., ... \& Murray, C. (2014). The global burden of low back pain: estimates from the Global Burden of Disease 2010 study. Annals of the rheumatic diseases, 73(6), 968-974.

2. Airaksinen, O., Brox, J. I., Cedraschi, C., Hildebrandt, J., KlaberMoffett, J., Kovacs, F., ... \& Zanoli, G. (2006). Chapter 4 European guidelines for the management of chronic nonspecific low back pain. European spine journal, 15, s192-s300.

3. Daniell, J. R., \& Osti, O. L. (2018). Failed Back Surgery Syndrome: A Review Article. Asian spine journal, 12(2), 372-379.

4. McCulloch J. A. Principles of microsurgery for Lumbar Disc Disease. Raven Press, New York, 1989.

5. Arseni C., Aldea H., Obreja Th. Hernia de disc lombara. Editura didactica si pedagogica Bucuresti, 1985, pp 7-9

6. Deyo, R. A., Gray, D. T., Kreuter, W., Mirza, S., \& Martin, B. I. (2005). United States trends in lumbar fusion surgery for degenerative conditions. Spine, 30(12), 1441-1445.

7. Deyo, R. A. (2007). Back surgery-who needs it. N Engl J Med, 356(22), 2239-2243

8. Burton, C. V. (2006). Failed back surgery patients: the alarm bells are ringing. Surgical neurology, 65(1), 5-6.

9. Elsberg CA: The extradural ventral chondromas, their favorite sites, the spinal cord and root symptoms they produce and their surgical treatment. Bull Neurol Inst NY 1:350-388 1931
- Surgical microscopy is clearly the main way to go regarding how we should operate degenerative diseases of the spine while mitigating additional risks.

- Always check the patient thoroughly for associated pathologies.

- Never neglect the spino-pelvic parameters, smoking, sedentariness and drinking.

- Psychiatric patients should always be examined using highly objective methods.

- A national review regarding financial compensation, pension granting and handicap reimbursement criteria should be performed.

- A clear definition of failed back surgery syndrome (as far as the Romanian healthcare system is concerned) is to be devised.

Compliance with ethics requirements: The authors declare no conflict of interest regarding this article. The authors declare that all the procedures and experiments of this study respect the ethical standards in the Helsinki Declaration of 1975, as revised in 2008(5), as well as the national law. Informed consent was obtained from all the patients included in the study.

10. Putti V: New conceptions in the pathologies of sciatic pain. Lancet 2:53, 1927

11. Mixter, W. J., \& Barr, J. S. (1934). Rupture of the intervertebral disc with involvement of the spinal canal. New England Journal of Medicine, 211 (5), 210-215.

12. Steinmetz, M. P., \& Benzel, E. C. (2016). Benzel's Spine Surgery E-Book: Techniques, Complication Avoidance, and Management. Elsevier Health Sciences.

13. Grotle, M., Småstuen, M. C., Fjeld, O., Grøvle, L., Helgeland, J., Storheim, K., ... \& Zwart, J. A. (2019). Lumbar spine surgery across 15 years: trends, complications and reoperations in a longitudinal observational study from Norway. BMJ open, 9(8), $\mathrm{e} 028743$.

14. Röder, C., El-Kerdi, A., Grob, D. et al. A European spine registry. Eur Spine J 11, 303-307 (2002).

15. Aghayev, E., Elfering, A., Schizas, C., Mannion, A. F., \& SWISSSpine Registry Group. (2014). Factor analysis of the North American Spine Society outcome assessment instrument: a study based on a spine registry of patients treated with lumbar and cervical disc arthroplasty. The Spine Journal, 14(6), 916-924.

16. L.W. Mysliwiec et al., MSU Classification for herniated lumbar discs on MRI: toward developing objective criteria for surgical selection. Eur Spine J (2010) 19:1087-1093 
